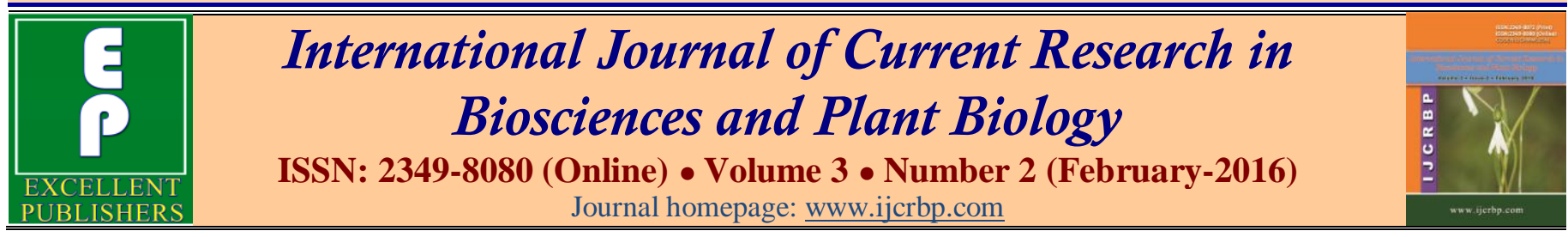

Original Research Article

doi: http://dx.doi.org/10.20546/ijcrbp.2016.302.011

\title{
Effect of Different Spacing on Growth and Yield of Carrot (Daucus carota L.) under Open and Subabul (Leucaena leucocephala) Based Agroforestry System
}

\author{
Nitin Umrao ${ }^{1}$, Rajiv Umrao ${ }^{2}$ and Arvind Bijalwan ${ }^{3 *}$ \\ ${ }^{1 \& 2}$ School of Forestry and Environment, SHIATS (Deemed to be University), Allahabad, U.P. India \\ 3 Indian Institute of Forest management (IIFM), Nehru Nagar, Bhopal-462 Oo3, M.P., India
}

*Corresponding author.

\section{Abstract}

The present study on effect of different spacing on growth and yield of carrot (Daucus carota L.) under open and Subabul (Leucaena leucocephala) based agroforestry system were statistically analyzed and explained with the help of tables and figures. A field experiment for the effect of different spacing has been conducted on carrot cv. (Golden Roji) during the Rabi season of 2014-2015. The different spacing of carrot under Subabul (Leucaena leucocephala) based agroforestry system were $(\mathrm{T} 1-15 \times 5 \mathrm{~cm}, \mathrm{~T} 2$ $15 \times 10 \mathrm{~cm}, \mathrm{~T} 3-15 \times 15 \mathrm{~cm}, \mathrm{~T} 4-20 \times 5 \mathrm{~cm}, \mathrm{~T} 5-20 \times 10 \mathrm{~cm}, \mathrm{~T} 6-20 \times 15 \mathrm{~cm}, \mathrm{~T} 7-25 \times 5 \mathrm{~cm}, \mathrm{~T} 8-$ $25 \times 10 \mathrm{~cm}$ andT $9-25 \times 15 \mathrm{~cm}$ ) for the study growth behaviour and yield attributes of carrot and analysis of Randomized Block Design with three replications. The plant height $(\mathrm{cm}$.$) , numbers of leaves per plant, root yield \mathrm{q} /$ ha was observed. The result shows that the maximum plant height, the maximum number of leaves per plant was found in treatment $\mathrm{T} 8(25 \times 10 \mathrm{~cm})$ in open condition and shade condition.
\end{abstract}

\section{Introduction}

Agroforestry means practice of agriculture and forestry on the same piece of land. Bene et al. (1979) defined agroforestry as a sustainable management system for land that increases overall production, combines agricultural crops, tree crops and forest plants and/or animals rearing simultaneously or sequentially and applies management practices these are compatible to the cultural pattern of the local population. Subabul (Leucaena leucocephala) belongs to the family Leguminaceae and sub-family Mimosaceae, it is also known as 'miracle tree' due to its paramount economic importance. It is a native of southern Mexico (region of Chimpus and Yucatan) has been introduced in many countries of the world namely pacific Islands, Philippines, Indonesia, Papua New Guinea, Malaysia, Eastern and Western Africa.). It also fixes atmospheric nitrogen equivalent to one tonne of ammonium sulphate per hectare per year assuming 1000 trees per hectare. Carrots (Daucus carota L.) belong to the family Umbelliferae (Peirce, 1987).

There are many vernacular names like Gajor, Gajjar, Karret, Mulangi are present in different region. The cultivated carrot probably originated in the Hills of the Punjab and Kashmir with a secondary centre of distribution in the Ethiopia and North Africa. According to Barnes (1936), $15.6^{\circ} \mathrm{C}$ to $21.1^{\circ} \mathrm{C}$ temperature is the ideal for its growth and development. The crop is tolerant to soil $\mathrm{pH}$ of 5.5 to 6.5 and it requires a deep and welldrained loamy soil with high amount of organic matter (Yayock et al., 1988). Higher and lower temperatures reduce the rate of growth and adversely affect the quality of the roots. Carrots do best under cool conditions (10 to $25^{\circ} \mathrm{C}$ ), and their seeds also germinate quite well, though 
slowly, under cool conditions.Plant spacing is one of the important factors for the increased production of carrot (Pavlek et al., 1977).

\section{Materials and methods}

The study was conducted on rabi season in the month of December 2014.The research work was carried out at the Research Farm of the Department of Agroforestry, School of Forestry and Environment, SHIATS Allahabad. The nine treatment was laid out in a randomized blocked design (RBD), using three replication. A field experiment for the effect of different spacing was conducted on carrot cv. (Golden Roji). The different spacing of carrot $\left(\mathrm{T}_{1}-15 \times 5 \mathrm{~cm}, \mathrm{~T}_{2^{-}}\right.$ $15 \times 10 \mathrm{~cm}, \mathrm{~T}_{3}-15 \times 15 \mathrm{~cm}, \mathrm{~T}_{4}-20 \times 5 \mathrm{~cm}, \mathrm{~T}_{5}-20 \times 10 \mathrm{~cm}, \mathrm{~T}_{6^{-}}$ $20 \times 15 \mathrm{~cm}, \mathrm{~T}_{7}-25 \times 5 \mathrm{~cm}, \mathrm{~T}_{8}-25 \times 10 \mathrm{~cm}$ and $\left.\mathrm{T}_{9}-25 \times 15 \mathrm{~cm}\right)$ for the crop to study growth behaviour and yield attributes of carrot. Carrot seeds were sown in a line to a depth of 1.5 to $2.0 \mathrm{~cm}$. The plots were manually weeded as the need arose.

\section{Results and discussion}

\section{Plant height (cm)}

From the Table 1 and Fig. 1, it was observed that the plant height $(\mathrm{cm})$ was significantly influenced by different treatment combinations at different spacing. At 30 DAS, it was observed that different treatment combination did significantly affect the plant height $(\mathrm{cm})$. The maximum plant height $(\mathrm{cm})$ was found in treatment $\mathrm{T}_{9}(7.32 \mathrm{~cm})$ followed by treatment $\mathrm{T}_{8}(6.11 \mathrm{~cm})$ in open condition and minimum plant height was observed in $\mathrm{T}_{3}(5.02 \mathrm{~cm})$. Maximum plant height under subabul based agroforestry system is found in $\mathrm{T}_{8}$ $(6.14 \mathrm{~cm})$, followed by $\mathrm{T}_{9}(6.11 \mathrm{~cm})$ and the minimum plant height was observed in $\mathrm{T}_{1}(3.8 \mathrm{~cm})$.

Table 1. Effect of different spacing on carrot (Daucus carota L.) on plant height (cm) under subabul (Leucaena leucocephala) based agroforestry system.

\begin{tabular}{|c|c|c|c|c|c|c|}
\hline \multirow{3}{*}{ Treatments } & \multicolumn{6}{|c|}{ Plant height $(\mathrm{cm})$} \\
\hline & \multicolumn{3}{|c|}{ Open condition } & \multicolumn{3}{|c|}{ Shade condition } \\
\hline & $30 \mathrm{DAS}$ & 60 DAS & $90 \mathrm{DAS}$ & $30 \mathrm{DAS}$ & 60 DAS & $90 \mathrm{DAS}$ \\
\hline $\mathrm{T}_{1}$ & 3.80 & 17.30 & 39.58 & 5.14 & 19.37 & 39.94 \\
\hline $\mathrm{T}_{2}$ & 4.31 & 18.72 & 40.40 & 5.45 & 18.36 & 39.62 \\
\hline $\mathrm{T}_{3}$ & 4.35 & 18.78 & 40.83 & 5.02 & 18.31 & 36.24 \\
\hline $\mathrm{T}_{4}$ & 4.55 & 19.00 & 39.86 & 5.39 & 20.06 & 40.37 \\
\hline $\mathrm{T}_{5}$ & 5.06 & 20.04 & 41.38 & 6.46 & 20.33 & 42.39 \\
\hline $\mathrm{T}_{6}$ & 4.64 & 20.30 & 41.91 & 5.56 & 20.05 & 41.64 \\
\hline $\mathrm{T}_{7}$ & 5.06 & 21.89 & 40.81 & 6.01 & 20.00 & 41.88 \\
\hline $\mathrm{T}_{8}$ & 6.14 & 23.77 & 44.94 & 6.11 & 20.93 & 42.30 \\
\hline $\mathrm{T}_{9}$ & 5.43 & 21.95 & 42.92 & 7.32 & 22.63 & 45.59 \\
\hline T test & $\mathbf{S}$ & $\mathbf{S}$ & $\mathbf{S}$ & $\mathbf{S}$ & $\mathbf{S}$ & $\mathbf{S}$ \\
\hline S. Ed. $( \pm)$ & 0.39 & 0.54 & 0.89 & 0.46 & 0.96 & 1.15 \\
\hline C.D. $(p=0.5 \%)$ & 0.84 & 1.14 & 1.90 & 0.98 & 1.02 & 2.43 \\
\hline
\end{tabular}

DAS - Days after sowing; S - Significant;

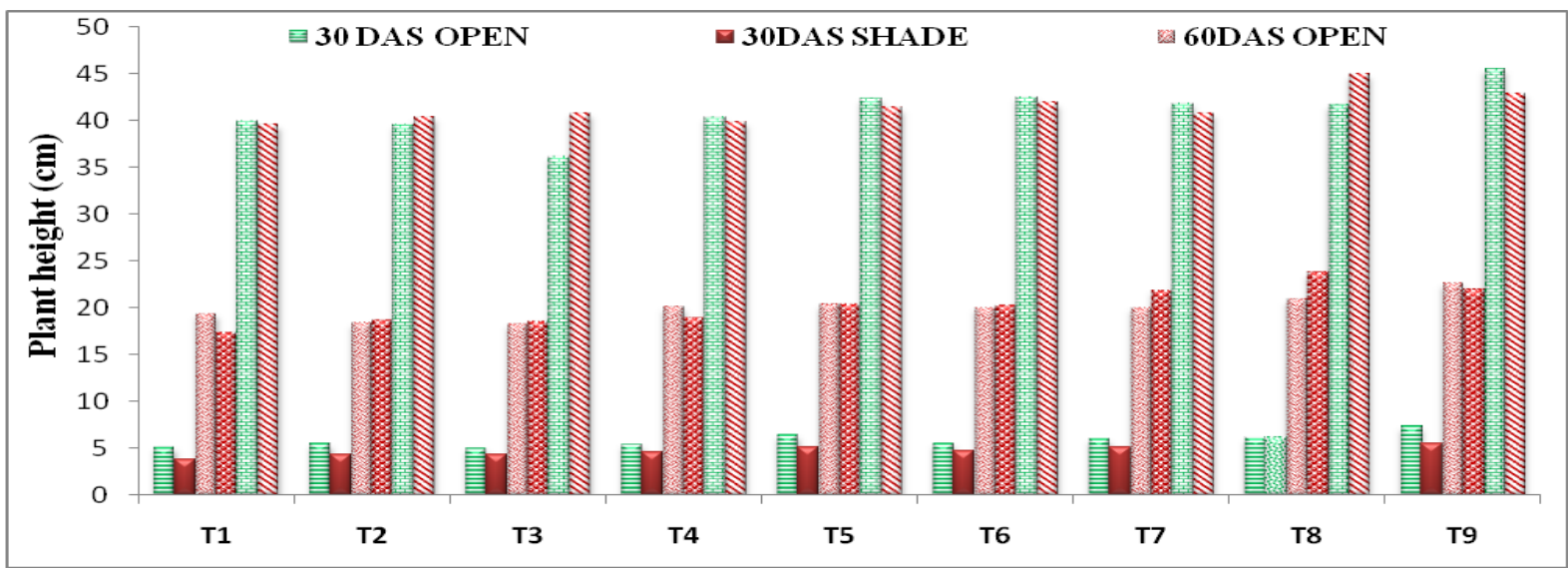

Fig. 1: Effect of different spacing on carrot (Daucus carota L) on plant height $(\mathrm{cm})$ under subabul (Leucaena leucocephala) based agroforestry system. 
At 60 DAS, it was observed that different treatment combination significantly affect the plant height $(\mathrm{cm})$. The maximum plant height $(\mathrm{cm})$ was found in treatment $\mathrm{T}_{9}(22.63 \mathrm{~cm})$ followed by treatment $\mathrm{T}_{8}(20.93 \mathrm{~cm})$ and minimum plant height was observed in $\mathrm{T}_{3}(18.31 \mathrm{~cm})$.Maximum plant height under subabul based agroforestry system is found in $\mathrm{T}_{8}(23.77 \mathrm{~cm})$, followed by $\mathrm{T}_{9}(21.95 \mathrm{~cm})$ and the minimum plant height was observed in $\mathrm{T}_{1}(17.30 \mathrm{~cm})$.

At 90 DAS, it was observed that different treatment combination significantly affect the plant height $(\mathrm{cm})$. The maximum plant height $(\mathrm{cm})$ was found in treatment $\mathrm{T}_{9}(45.59 \mathrm{~cm})$ followed by treatment $\mathrm{T}_{8}(42.3 \mathrm{~cm})$ and minimum plant height was observed in $T_{3}$ $(36.24 \mathrm{~cm})$.Maximum plant height under subabul based agroforestry system is found in $\mathrm{T}_{8}(44.94 \mathrm{~cm})$, followed by $\mathrm{T}_{9}(42.92 \mathrm{~cm})$ and the minimum plant height was observed in $\mathrm{T}_{1}(39.58 \mathrm{~cm})$. This result similar to Ijoyah et al. (2010) reported that at $25 \mathrm{~cm}$ inter-row spacing the maximum plant height was $93.3 \mathrm{~cm}$ in okra under open condition. Similar result was reported Kumar et al. (2015) who reported that at $20 \mathrm{~cm}$ inter-rows spacing the maximum plant height was $66.86 \mathrm{~cm}$ on linseed in teak based agroforestry system. The findings confirmed by Ibeawuchi et al. (2005) showed that in okra plant $R_{30}$ $(30 \times 50 \mathrm{~cm})$ maximum plant $(113 \mathrm{~cm})$ height and minimum plant height $(79.0 \mathrm{~cm})$ was reported in widest row spacing $R_{75}(75 \times 50 \mathrm{~cm})$. Similar results were obtained by Randhawa and Pannum (2000).

\section{Number of leaves at different intervals}

From the Table 2 and Fig. 2, it was observed that the number of leaves at different intervals was significantly influenced by different treatment combinations at different spacing. At $30 \mathrm{DAS}$, it was observed that different treatment combination non- significantly affect the Number of leaves. The maximum number of leaves was found in open treatment $T_{9}$ (3.6) followed by treatment $\mathrm{T}_{8}$ (3.06) and minimum number of leaves was observed in $\mathrm{T}_{3}$ (2.53). Maximum number of leaves was observed under subabul based agroforestry system in the treatment number $\mathrm{T}_{8}$ (3.33), followed by treatment number $\mathrm{T}_{9}$ (3.06) and minimum number of leaves was found in treatment $\mathrm{T}_{1}(2.40)$.

Table 2. Effect of different spacing on number of leaves of carrot (Daucus carota L.) under subabul (Leucaena leucocephala) based agroforestry system.

\begin{tabular}{|c|c|c|c|c|c|c|}
\hline \multirow{3}{*}{ Treatments } & \multicolumn{6}{|c|}{ Number of leaves per plant } \\
\hline & \multicolumn{3}{|c|}{ Open condition } & \multicolumn{3}{|c|}{ Shade condition } \\
\hline & $30 \mathrm{DAS}$ & $60 \mathrm{DAS}$ & 90 DAS & $30 \mathrm{DAS}$ & $60 \mathrm{DAS}$ & $90 \mathrm{DAS}$ \\
\hline $\mathrm{T}_{1}$ & 3.20 & 5.53 & 9.33 & 2.40 & 4.60 & 6.26 \\
\hline $\mathrm{T}_{2}$ & 2.66 & 5.66 & 8.33 & 2.46 & 5.53 & 6.83 \\
\hline $\mathrm{T}_{3}$ & 2.53 & 5.00 & 8.33 & 2.93 & 5.73 & 7.00 \\
\hline $\mathrm{T}_{4}$ & 3.00 & 6.40 & 8.86 & 2.66 & 5.46 & 7.26 \\
\hline $\mathrm{T}_{5}$ & 2.63 & 6.26 & 8.80 & 2.46 & 5.26 & 8.06 \\
\hline $\mathrm{T}_{6}$ & 2.86 & 6.13 & 8.66 & 3.20 & 5.40 & 8.20 \\
\hline $\mathrm{T}_{7}$ & 3.00 & 6.33 & 9.02 & 3.13 & 5.53 & 8.40 \\
\hline $\mathrm{T}_{8}$ & 3.06 & 5.40 & 7.73 & 3.33 & 6.33 & 9.66 \\
\hline $\mathrm{T}_{9}$ & 3.60 & 7.06 & 9.93 & 3.06 & 5.73 & 8.20 \\
\hline T test & NS & $\mathrm{S}$ & $\mathrm{S}$ & NS & $\mathrm{S}$ & $\mathrm{S}$ \\
\hline S. Ed. $( \pm)$ & 0.30 & 0.45 & 0.49 & 0.33 & 0.35 & 0.59 \\
\hline C.D. $(p=0.05 \%)$ & 0.64 & 0.95 & 1.04 & 0.71 & 0.74 & 1.25 \\
\hline
\end{tabular}

DAS - Days after sowing; S - Significant;

At 60 DAS, it was observed that different treatment combination significantly affect the number of leaves at different intervals. The maximum number of leaves at different intervals was found in open treatment $T_{9}$ (7.06) followed by treatment $T_{5}(6.26)$ and minimum number of leaves at different intervals was observed in $\mathrm{T}_{3}(5.00)$. Maximum number of leaves was observed under subabul based agroforestry system in the treatment $\mathrm{T}_{8}$ (6.33), followed by treatment number $\mathrm{T}_{9}(5.73)$ and $\mathrm{T}_{3}(5.73)$ and the minimum number of leaves was found in treatment
Number $T_{1}$ (4.60). At 90 DAS, it was observed that different treatment combination significantly affect the number of leaves at different intervals. The maximum number of leaves at different intervals was found in open treatment $\mathrm{T}_{9}(9.93)$ followed by treatment $\mathrm{T}_{7}(9.02)$ and minimum number of leaves at different intervals was observed in $\mathrm{T}_{2}$ (8.33) and $\mathrm{T}_{3}$ (8.33). Maximum number of leaves was observed under subabul based agroforestry system in the treatment number $\mathrm{T}_{8}(9.66)$, followed by treatment number $\mathrm{T}_{7}(8.40)$ and minimum number of 
leaves was found in treatment number $\mathrm{T}_{1}(6.23)$. This result is similar to Bussell and Dallenger et al. (1972) who reported different spacing variation from 9.44 to 14.46. The maximum number of leaves (14.46) was found at $30 \mathrm{~cm} \times 20 \mathrm{~cm}$ spacing $(\mathrm{S} 3)$ and the minimum (9.44) was found at $20 \mathrm{~cm} \times 10 \mathrm{~cm}$ spacing (S1) because plants at $30 \mathrm{~cm} \times 20 \mathrm{~cm}$ spacing could uptake more nutrients than other plants due to higher spacing.

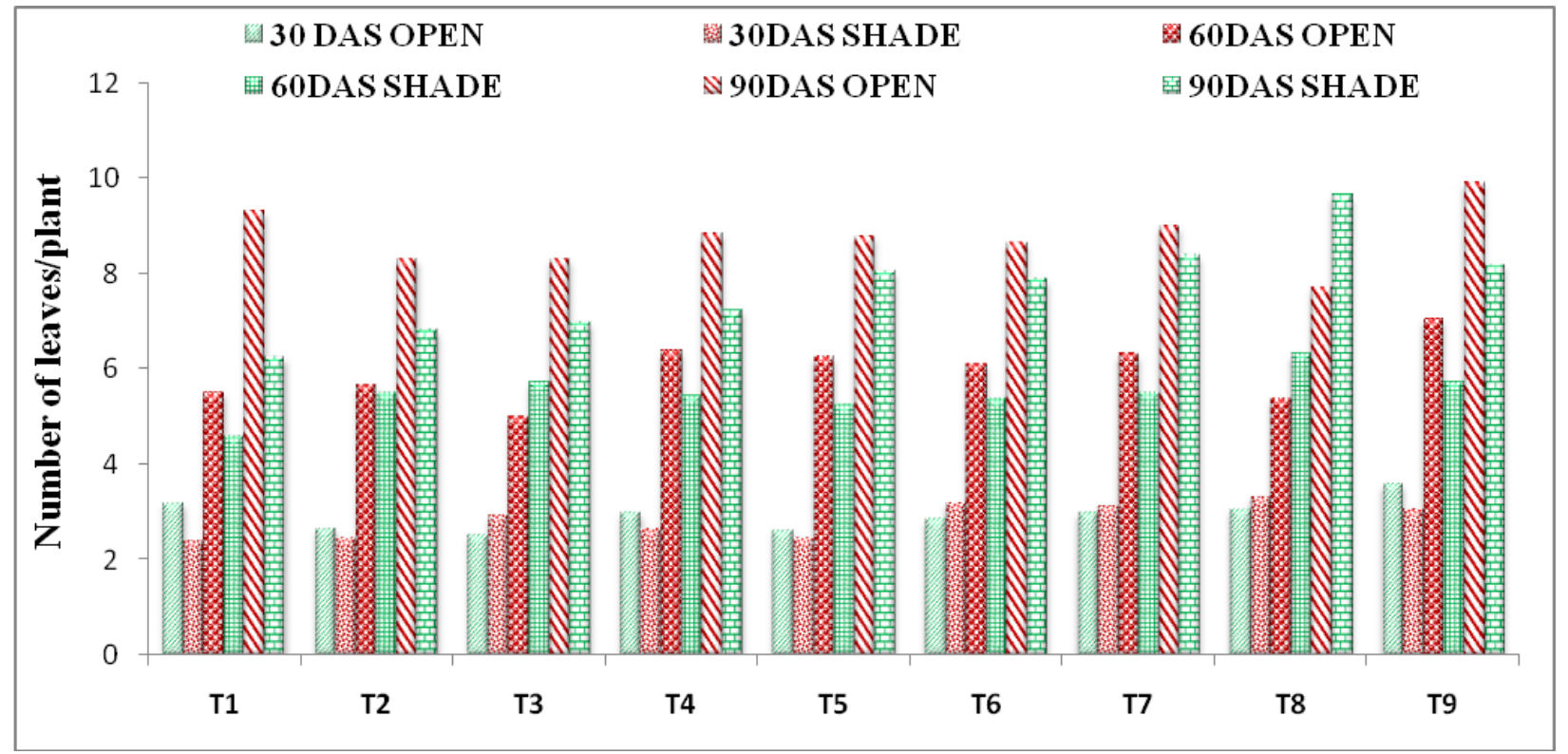

Fig. 2: Effect of different spacing on carrot (Daucus carota L.) on number of leaves under subabul (Leucaena leucocephala) based agroforestry system.

\section{Root yield (qt/ha)}

From Table 3 and Fig. 3, it was observed that the root yield (qt/ha.) was significantly influenced by different treatment combinations at different spacing. It was observed that different treatment combination did significantly affect by spacing, the root yield (qt/ha). The maximum root yield (qt /ha) was found in treatment $T_{5}$
(159 qt/ha) followed by treatment $\mathrm{T}_{6}(157.33 \mathrm{qt} / \mathrm{ha})$ and minimum root yield was observed in $\mathrm{T}_{9}(109 \mathrm{qt} / \mathrm{ha})$. It was observed that different treatment combination did significantly affect by spacing under subabul based agroforestry system. The maximum root yield (qt/ha) was found in treatment $T_{5}(152.5 \mathrm{q} / \mathrm{ha})$ followed by treatment $\mathrm{T}_{6}(142.33 \mathrm{qt} / \mathrm{ha})$ and minimum root yield was observed in $\mathrm{T}_{5}(106.66 \mathrm{qt} / \mathrm{ha})$.

Table 3. Effect of different spacing on carrot (Daucus carota L.) root yield quintal / hectare in open and under subabul (Leucaena leucocephala) based agroforestry system.

\begin{tabular}{lll}
\hline \multirow{2}{*}{ Treatments } & Root yield $(\mathbf{q} /$ ha) & Shade condition \\
\cline { 2 - 3 } & Open condition & 121.66 \\
$\mathrm{~T}_{1}$ & 137.50 & 125.00 \\
$\mathrm{~T}_{2}$ & 134.83 & 114.16 \\
$\mathrm{~T}_{3}$ & 156.66 & 106.66 \\
$\mathrm{~T}_{4}$ & 143.33 & 152.50 \\
$\mathrm{~T}_{\mathbf{5}}$ & 159.00 & 142.33 \\
$\mathrm{~T}_{6}$ & 157.33 & 137.66 \\
$\mathrm{~T}_{7}$ & 119.16 & 135.83 \\
$\mathrm{~T}_{8}$ & 115.00 & 108.33 \\
$\mathrm{~T}_{9}$ & 109.00 & $\mathbf{S}$ \\
$\mathbf{T}$ test & $\mathbf{S}$ & $\mathbf{9 . 9 6}$ \\
$\mathbf{S}$. Ed. $( \pm)$ & $\mathbf{1 2 . 0 8}$ & $\mathbf{2 1 . 1 2}$ \\
C.D. $(\mathbf{P}=\mathbf{0 . 0 5 \%})$ & $\mathbf{2 5 . 6 0}$ & \\
\hline $\mathrm{S}-$ Significant. & &
\end{tabular}




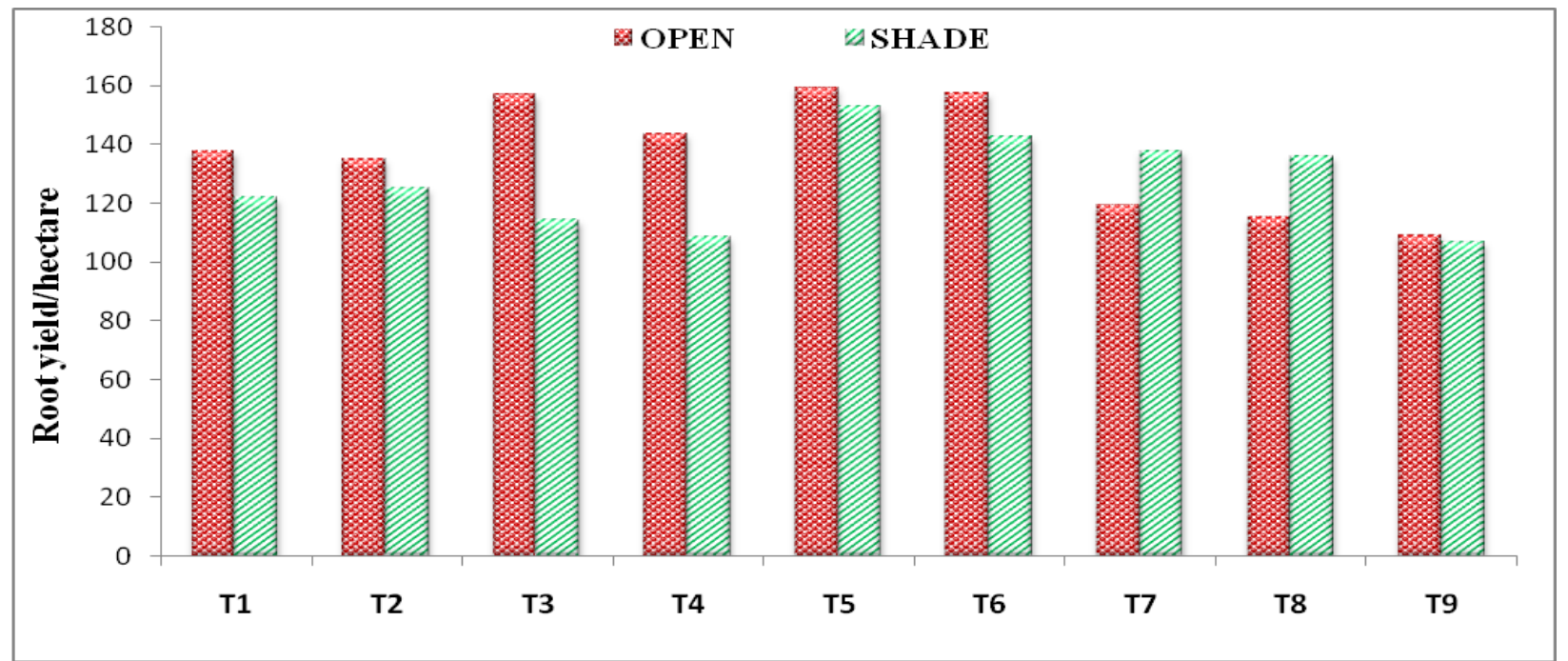

Fig. 3: Effect of different spacing on carrot (Daucus carota L.) root yield quintal / hectare in open and under subabul (Leucaena leucocephala) based agroforestry system.

\section{Conclusion}

The present study concluded that the experimental observations obtained during the investigation, that treatment $\mathrm{T}_{5}$ i.e.spacing $15 \mathrm{X} 10 \mathrm{~cm}$ emerged as the most superior over all the other spacing with regard to its growth performance and yield attributes both in open condition and under subabul based agroforestry system. So this spacing of carrot is highly recommended for cultivation under subabul based agroforestry system during Rabi season in Allahabad conditions.

\section{Conflict of interest statement}

Authors declare that they have no conflict of interest.

\section{References}

Barnes, N.C., 1936. Effect of some environmental factors on growth and colour of carrots. Bulletin Cornell Univ. Agric. Expt. Sta., pp: 186.

Bene, J.G., Beall, H.W., Cote, A., 1977. Trees, Food and People. IDRC, Ottawa, Canada.

Bussell, W.T., Dallenger, J., 1972. Baby carrot: a report on main crop varieties trials. NZ Commer. Grower 27(9), 29-31.
Ibeawuchi, I.I., Obiefuna, J.C., Ofoh, M.C., 2005. Effect of row spacing on yield and yield components of okra and mixture groundnut (Archis hypogeaea). J. Agron. 4(4), 304-307.

Ijoyah, M. O., Unah, P. O., Fanen, F. T., 2010. Response of okra (Abelmoschus esculentus L. Moench) to intra-row spacing in Makurdi, Nigeria. Agric. Biol. J. North Amer. $1(6), 1328-1332$.

Kumar, H., Umrao, R., Tripathi, M.K., 2015. Varietal performance of linseed (Linum usitatissimum) planted at different pacing under teak (Tectona grandis) based agroforestry system. J. Int. Acad. Res. Multidiscip. 2(8), 261-268.

Pavlek, P., 1977. Effect of plant density on carrot yield. Plojprivr. Znanstv. Smotra. 42, 67-73.

Peirce, L. C., 1987. Vegetable: Characteristics, Production and Marketing, John Wiley and Sons.

Randhawa, G. S., Pannum, M. S., 2000. The effects of row spacing on the growth and yield of okra. Punjab Agric. Univ. Res. J. 6, 320-324.

Yayock, J.Y., Lombin, G., Owonubi, J.J., Onazi, O.C., 1988. Crop Science and Production in Warm Climates. Macmillan Publishers, London. pp.133-138.

\section{How to cite this article: \\ Umrao, N., Umrao, R., Bijalwan, A., 2016. Effect of different spacing on growth and yield of carrot (Daucus carota L.) under open and subabul (Leucaena leucocephala) based agroforestry system. Int. J. Curr. Res. Biosci. Plant Biol. 3(2), 91-95. \\ doi: http://dx.doi.org/10.20546/ijcrbp.2016.302.011

